\title{
Is social isolation during the COVID-19 pandemic a risk factor for depression?
}

\author{
Seria o isolamento social durante a pandemia de COVID-19 um fator de risco para depressão? \\ ¿Sería el aislamiento social durante la pandemia de COVID-19 un factor de riesgo para depresión?
}

Adaene Alves Machado de Moura'
ORCID: 0000-0001-7607-9841

Igor Roberto Bassoli

ORCID: 0000-0003-0290-5578

Belisa Vieira da Silveira' ORCID: 0000-0002-5966-8537

Alessandra Diehl

ORCID: 0000-0002-9252-3284

Manoel Antônio dos Santos' ORCID: 0000-0001-8214-7767

Ronildo Alves dos Santos' ORCID: 0000-0003-3364-7727

Christopher Wagstaff"

ORCID: 0000-0002-8013-1195

Sandra Cristina Pillon ORCID: 0000-0001-8902-7549

'Universidade de São Paulo. Ribeirão Preto, São Paulo, Brazil. "University of Birmingham. Birmingham, England.

How to cite this article: Moura AAM, Bassoli IR, Silveira BV, Diehl A, Santos MA, Santos RA, et al. Is social isolation during the COVID-19 pandemic a risk factor for depression? Rev Bras Enferm. 2022;75(Suppl 1):e20210594. https://doi.org/10.1590/0034-7167-2021-0594

Corresponding author:

Adaene Alves Machado de Moura E-mail: adaene_moura@usp.br

EDITOR IN CHIEF: Álvaro Sousa ASSOCIATE EDITOR: Hugo Fernandes

Submission: 01-17-2021

Approval: 11-04-2021

\begin{abstract}
Objective: To assess factors associated with depression among higher education students and professionals during the peak of the COVID-19 pandemic. Method: quantitative study with a cross-sectional design. 550 students and professionals participated. The data were collected by means of a digital questionnaire that included Patient Health Questionnaire- 9 to assess depressive symptoms. Results: The factors related to depression and social isolation outcomes were significantly associated with the female gender $(n=149 ; 37,8 \%$; Odds Ratio $O R=2,0)$, white $(n=127 ; 37,2 \% ; O R=1,60)$, young people $(n=130 ; 39,4 \% ; O R=2,0)$, without religion $(n=70 ; 40,2 \%$; $\mathrm{OR}=1,64)$, with financial problems $(n=80 ; 53,0 \% ; O R=2,40)$ and family problems $(n=98 ; 47,3 \%$; $\mathrm{OR}=1,77)$; who suffered violence during the quarantine $(n=28 ; 58,3 \%$; $O R=2,33)$, increased the use of illicit drugs ( $n=16 ; 59,3 \%$; $O R=2,69)$, used sedatives without a medical prescription $(n=75 ; 54,0 \% ; O R=2,94)$, lived in conflicting relationships $(n=33 ; 54,1 \% ; O R=2,14)$, lost their job during the pandemic $(n=32 ; 59,3 \% ; O R=1,99)$ and presented symptoms of anxiety related to COVID-19 ( $n=155 ; 45,2 \%$; OR=3,91). Conclusion: there is a meaningful relationship between vulnerability and adopting risk behaviors during the pandemic-imposed social isolation with depressive symptoms. We suggest that health professionals be attentive to the need to adjust their psychosocial interventions when promoting strategies when promoting strategies to mitigate the effects and risks to mental health.
\end{abstract}

Descriptors: COVID-19; Depression; Social Isolation; Mental Health; Pandemics.

\section{RESUMO}

Objetivo: Avaliar os fatores associados à depressão entre estudantes e profissionais de nível superior durante o pico da pandemia de COVID-19. Método: estudo quantitativo com delineamento transversal. Participaram 550 estudantes e profissionais. Os dados foram coletados por meio de um questionário digital, que incluía o Patient Health Questionnaire-9 para avaliação de sintomas depressivos. Resultados: Os fatores relacionados à depressão e os desfechos do isolamento social foram significantemente associados ao sexo feminino ( $n=149 ; 37,8 \%$; Odds Ratio $O R=2,0)$, raça branca $(n=127 ; 37,2 \% ; O R=1,60)$, jovens $(n=130 ; 39,4 \% ; O R=2,0)$, sem religião ( $n=70 ; 40,2 \% ; O R=1,64)$, com problemas financeiros $(n=80 ; 53,0 \% ; O R=2,40)$ e familiares $(n=98 ; 47,3 \% ; O R=1,77)$, que sofreram violência durante a quarentena $(n=28 ; 58,3 \% ; O R=2,33)$, aumentaram o uso de drogas ilícitas ( $n=16 ; 59,3 \%$; $O R=2,69)$, consumiram sedativos sem prescrição médica ( $n=75 ; 54,0 \% ; O R=2,94)$, vivenciaram relacionamentos conflituosos ( $n=33$; $54,1 \% ; \mathrm{OR}=2,14)$, perderam o emprego na pandemia $(n=32 ; 59,3 \% ; \mathrm{OR}=1,99)$ e apresentaram sintomas de ansiedade relacionada à COVID-19 $(n=155 ; 45,2 \% ; O R=3,91)$. Conclusão: há uma relação significativa entre vulnerabilidade e adoção de comportamentos de risco durante o isolamento social imposto pela pandemia com sintomas depressivos. Sugerimos que os profissionais de saúde estejam atentos para a necessidade de ajustar suas intervenções psicossociais ao promoverem estratégias para mitigar os efeitos e riscos à saúde mental. Descritores: COVID-19; Depressão; Isolamento Social; Saúde Mental; Pandemias.

\section{RESUMEN}

Objetivo: Evaluar los factores asociados a la depresión entre estudiantes y profesionales de nivel superior durante el pico de la pandemia de COVID-19. Método: estudio cuantitativo con delineamiento transversal. Participaron 550 estudiantes y profesionales. Los datos fueron obtenidos por medio de un cuestionario digital, que incluía el Patient Health Questionnaire-9 para evaluación de síntomas depresivos. Resultados: Los factores relacionados a la depresión y los resultados del aislamiento social fueron significativamente asociados al sexo femenino ( $n=$ $149 ; 37,8 \%$; Odds Ratio $O R=2,0)$, raza blanca $(n=127 ; 37,2 \% ; O R=1,60)$, jóvenes $(n=130 ; 39,4 \%$; $\mathrm{OR}=2,0)$, sin religión $(n=70 ; 40,2 \% ; O R=1,64)$, con problemas financieros $(n=80 ; 53,0 \% ; O R=2,40)$ y familiares $(n=98 ; 47,3 \% ; O R=1,77)$; que sufrieron violencia durante la cuarentena $(n=28$; $58,3 \%$; $\mathrm{OR}=2,33$ ), aumentaron el uso de drogas ilícitas $(n=16 ; 59,3 \%$; $\mathrm{OR}=2,69)$, consumieron sedativos sin prescripción médica $(n=75 ; 54,0 \% ; O R=2,94)$, vivieron relaciones conflictivas $(n=33$; $54,1 \% ; \mathrm{OR}=2,14)$, perdieron el empleo en la pandemia $(n=32 ; 59,3 \% ; \mathrm{OR}=1,99)$ y presentaron síntomas de ansiedad relacionado al COVID-19(n=155; 45,2\%; OR=3,91). Conclusión: Hay una relación significativa entre vulnerabilidad y adopción de comportamientos de riesgo durante el aislamiento social impuesto por la pandemia con síntomas depresivos. Sugerimos que los profesionales de la salud estén atentos ante la necesidad de ajustar sus intervenciones psicosociales al promover estrategias para mitigar los efectos y riesgos para la salud mental. Descriptores: COVID-19; Depresión; Aislamiento Social; Salud Mental; Pandemias. 


\section{INTRODUCTION}

In a scenario marked by complex and rapid technological evolution, 2020 began with an unprecedented challenge for the health care industry, with serious repercussions on the population's mental health. With an origin in China, the new, highly transmissible coronavirus (SARS-CoV-2) - COVID-19 causing agent - rapidly disseminated across that country, reaching pandemic proportions within a few months, causing a global public health challenge with serious social and economic consequences ${ }^{(1)}$.

In an attempt to contain the accelerated transmissibility, some countries decreed quarantine, among other social distancing measures adopted in the attempt to interrupt virus circulation and dissemination ${ }^{(2)}$. The restrictive social transit measures had negative repercussions on the population's life, causing the population to abruptly change its routines in different spheres, impacting family daily life, work environment, studies, and community social life.

In the unusual scenario presented, sanitary measures forced the interruption of all non-essential services, suspension of school and university classes, closing of business and commerce without a deadline for a return to normality. Adopting other, nonpharmacological strategies with a view to controlling the virus' accelerated transmission also showed to be necessary. Changes in everyday life resulted in numerous repercussions on mental health, generating generalized psychological suffering. The sanitary measures, however, are distributed disproportionately across different strata of the population, with some social segments presenting more vulnerability than others. One of the most vulnerable groups are students, who manifested various levels of anxiety, depression, and stress throughout the pandemic ${ }^{(3)}$. Another group that was uniquely affected by work stress was that of health professionals, especially those who work on the front line of care treating patients diagnosed with COVID-19(1), with emphasis on women and young people ${ }^{(4)}$.

A study conducted in Kuwait verified the susceptibility to mental illness among health professionals and undergraduate students during the COVID-19 pandemic. The survey revealed that $66.6 \%$ of the participants had symptoms of severe or moderately severe depression, measured by a specific instrument (PHQ- 9) (5). Another screening study also conducted through an online platform in Mexico, at the beginning of the beginning of the pandemic (March to May 2020), found that students, including undergraduate and graduate students, were experiencing negative feelings. The authors concluded that the participants presented mental suffering and low energy levels ${ }^{(3)}$. Thus, manifestations of psychological distress during the pandemic have been affecting undergraduate and graduate students, in addition to professionals with higher education.

There is a consensus established in the literature that traumas resulting from natural disasters and catastrophes, tragedies, major diseases, epidemics, and pandemics cause direct damage to people's mental health, potentiating their vulnerability to depressive episodes ${ }^{(2,6)}$. However, literature is still incipient regarding potential risk factors associated with social isolation and depression in the different population groups.

No Brazilian studies were found that evaluated the depression and isolation rates among students and professionals of several fields. Overall, studies focus on a certain category, such as health professionals ${ }^{(7-8)}$ or students from general or specific courses ${ }^{(9)}$.

Thus, it is noted that little attention has been given specifically to assessing the relationship between social isolation and symptoms of depression among diverse groups of professionals with higher education. Identifying the characteristics of this association can contribute evidence that enables better assistance strategies for support and psychosocial monitoring aimed at the demands of different population groups. Based on the lessons apprehended when fighting other epidemics, we can suppose that, in the period that comprised the first six months of COVID-19, there may have been an increase in depression rates and/or increase in symptoms such as worry, fear, anxiety, suicide ideation, in addition to a growth in domestic violence, weakening of social protection networks, use and abuse of alcohol and other substances ${ }^{(10)}$.

Considering this perspective, we formulated the following research question: "is there a relationship between social isolation and symptoms of depression during the COVID-19 pandemic?" Considering this question, we hypothesized that social distancing measures, such as domestic confinement and constant concerns about life threatening issues are intimately related to symptoms of depression.

\section{OBJECTIVE}

To assess factors associated with depression among higher education students and professionals during the peak of the COVID-19 pandemic.

\section{METHOD}

\section{Ethical aspects}

The study was approved by the Ethics Committee in Research with Human Beings of the institution to which the researcher is affiliated. Information about the justification, objectives and procedures involved in the research were made available on the first page of the electronic form. The study followed the ethical guidelines established by Resolution 466/2012 of the National Council for Research Ethics (CONEP). Participants expressed their consent by signing the Free and Informed Consent Form (FICF) made available electronically.

\section{Study design, period, and site}

This is a quantitative cross-sectional study conducted according to the guidelines recommended by Reporting of Observational Studies in Epidemiology (STROBE) ${ }^{(11)}$ and guided by the Checklist for Reporting Results of Internet E-Surveys (CHERRIES) ${ }^{(12)}$.

\section{Sample and inclusion criteria}

The non-probabilistic sample consisted of 550 higher education students and professionals of different fields residing in all regions of Brazil, with 241 (43.7\%) undergraduates or graduates, $80(14.5 \%)$ with a non-masters or doctoral graduate course, 110 (20.0\%) with a master's (complete/incomplete), 107 (19.4\%) with a doctorate (complete/incomplete) and $13(2.4 \%)$ with a postdoctoral 
degree (complete/incomplete). The eligibility criteria established the inclusion of individuals with an age equal to or older than 18 of all genders, undergraduate, graduate, specialization students and higher education professionals, users of any digital social network.

\section{Data collection procedures}

Sample recruitment and the invitation to the study was performed online using the main social networks (Facebook, WhatsApp, and Instagram). This procedure was adopted due to the impossibility of in person contact with the participants during the period of the COVID-19 pandemic. A link was also provided for access to the form. The participant had the option of expressing their acceptance by means of the declaration at the end of the FICF. Then, the platform directed them to the form containing the instruments used for data collection. The data were collected through a questionnaire made available in digital format using the Google Forms platform. The invitation was made available online for seven consecutive days, between August 7th and 13th, 2020.

\section{Instruments}

A three-part questionnaire was developed with the following variables:

- Sociodemographic information: gender, age, race, education, religion, income, work, financial struggles, family problems, marital relationship.

- Variables related to personal health and well-being: access to information about COVID-19, job loss during the pandemic, excessive concern about the new coronavirus, violence, participation in festive activities, use of psychoactive substances regardless of their legality, and sleep quality.

- Patient Health Questionnaire-9(PHQ-9): This instrument is used to identify symptoms of depression and classify them according to levels of severity, considering the last two-week period prior to application. PHQ-9 was developed based on the diagnostic criteria of the Diagnostic and Statistical Manual of Mental Disorders (DSM) IV, comprised by nine items, which vary from zero to 27 points. The answer options for each item range from zero to three points, allowing the depression to be classified into four levels of severity: mild (5 points), moderate (10 points), moderately severe (15 points) and severe (20 points). However, it is understood that a score equal to or greater than 15 characterizes the presence of major depression in individuals ${ }^{(13)}$, and those under that score being considered a negative depression. This was the score used in this study. The PHQ-9 has a satisfactory level of reliability (Cronbach's alpha - 0.89) to identify positive cases of depression ${ }^{(13)}$.

\section{Statistical analysis}

The data collected data were stored on the Google Forms platform and in Microsoft Excel 2016. The Statistical Package on Social Science (SPSS), Windows version 22.0 was subsequently used. The data are presented in absolute frequency $(n)$ and percentage (n) and percentage (\%) to characterize the sample in relation to covariates. A bivariate analysis was initially performed through Pearson's chi-square test to assess the association between the outcome variable (depression) with the predictors (sociodemographic, economic, and behavioral data during the pandemic). Logistic regression analysis was performed to quantify the relationship between the positive depression variable (dependent variable) and the predictor variables (sociodemographic and information related to health, well-being and use of substances during the pandemic). The Un-adjusted Odds Ratio (OR) related to each predictor for positive depression was calculated. Later, the Adjusted Odds Ratio (ORA) was used to parsimoniously assess the relationship with each predictor variable for depression involving a smaller number of variables. A significance value of $\mathrm{p}<0.05$ with a Confidence Interval $(\mathrm{Cl})$ of $95 \%$ was considered in all statistical analyses. Given that this study was conducted with social network users, calculating the sample size was not possible.

\section{RESULTS}

Of the 550 (100\%) participants, most were female $71.6 \%(n=394)$, white $62.0 \%(n=341)$, young with an average age of 29.3 years old (standard deviation 8.0), ranging between 18 and 68 years old, $56.4 \%$ with a graduate education $(n=310), 68.4 \%(n=376)$ had a religion, $38.4 \%(n=226)$ had family income $\geq 4$ minimum wages, and $61.1 \%(n=359)$ were working. Of the total, $151(27.5 \%)$ said they had a conflicting marital relationship (Table 1 ).

The depressive symptoms were classified as: mild 162 (29.5\%), moderate 122 (22.2\%), moderately severe 95 (17.3\%) and severe 91 (16.5\%), which were regrouped into two groups, 33.8\% $(n=186)$ positive depression and 364 (66.2\%) negative depression (PHQ-9). The participants with depression differed by being female $37.8 \%$ $(n=149), 39.4 \%$ young ( 18 to 29 years old) $(n=130), 37.2 \%$ white $(n=127), 40.2 \%$ did not profess a religion $(n=70), 43.6 \%$ had a family income $<2$ minimum wages $(n=48), 39.0 \%$ did not work $(n=83)$, half were experiencing financial difficulties $53.0 \%(n=83)$, $47.3 \%$ had a family issues $(n=98)$ and $54.1 \%$ were experiencing a conflicting or mixed marital relationship $(n=33)$, with statistically significant values $(\mathrm{p}<0.05)$ (data available in Table 1$)$.

In the multivariate analysis, female participants (OR=2 [Cl95\% 1.27;3.18]; $\mathrm{p}<0.05)$, age (18-29 years) ( $\mathrm{OR}=2.0$ [CI95\% 1.31;3.21]; $\mathrm{p}<0.05)$ presented doubled odds ratios between the group with positive depression when compared to males and adults. Furthermore, those of white race/white skin color had greater odds ratios among the group with positive depression $(\mathrm{OR}=1.60$ [CI95\%=1.06;2.42]; $\mathrm{p}<0.05$ ). People who did not profess a religion had higher chances of presenting depressive symptoms ( $\mathrm{OR}=1.64$ [C195\% 1.08;2.49]; $\mathrm{p}<0.05)$. Individuals who reported financial struggles ( $O R=240$ [CI95\% 1.52;3.79]; $\mathrm{p}<0.05)$; family issues (OR=1.77; Cl95\% 1.17;2.68; $\mathrm{p}<0.05)$ and conflicting/mixed marital relationship ( $O R=2.14$ [CI95\% 1.10;4.15]; $\mathrm{p}<0.05)$ had an increased probability among the participants in the group with positive depression (Table 1).

The most used substances in the last three months were: $77.3 \%$ $(n=425)$ alcohol, $20.4 \%(n=112)$ sedatives, $17.1 \%(n=94)$ tobacco, $14.5 \%(n=80)$ marijuana and $2.7 \%(n=15)$ cocaine/crack. 5.8\% $(n=32)$ of the sample reported a diagnosed anxiety disorder as a pre-existing morbidity. 
Of the total sample, $3.8 \%(n=210$ had a positive COVID-19 diagnosis confirmed by exams, $49.8 \%(n=274)$ had a family member/close person with the disease, $9.8 \%(n=54)$ lost their jobs during the pandemic. Most $93.5 \%(n=514)$ reported feeling concerned and $62.4 \%(n=343)$ had symptoms of anxiety; on the other hand, $24.0 \%(n=132)$ participated in festive events where they exposed themselves to crowding. Also, in relation to risk factors, $8.7 \%(n=48)$ suffered some type of violence, $25.3 \%$ $(n=139)$ used medication (tranquillizers/sedatives) without medical indication, $60.9 \%(n=335)$ used alcoholic beverages to relieve tension, stress, or anxiety and $4.9 \%(n=27)$ increased the consumption of illicit drugs,

Participants with positive depression differed in the sample due to the following: $59.3 \%(n=32)$ lost their jobs during the pandemic, $45.2 \%(n=22)$ had symptoms of anxiety. $58.3 \%(n=28)$ suffered violence during quarantine, $54.0 \%(n=75)$ made use of medication (psychotropic) without medical indication, and 59.3\% $(n=16)$ increased the use of illicit drugs during the quarantine $(p<0.05)$.

In the multivariate analysis, the people who presented symptoms of anxiety due to the pandemic (OR=3.91 [CI95\%=2.44;6.27]; $\mathrm{p}<0.05)$ were victims of violence ( $O R=2.33$ [CI95\% 1.18;4.55]; $p<0.05)$, used (psychotropic) medications without medical indication (OR=2.94; [Cl95\% 1.88;4.51]; $\mathrm{p}<0.05)$ and increased use of illicit drugs $(\mathrm{OR}=2.69$ $[C \mid 95 \% 1.08 ; 6.68] ; \mathrm{p}<0.05)$ presented the highest odds rations among those identified with positive depression (PHQ-9) (Table 2).

\section{DISCUSSION}

More than three out of three out of 10 participants from our sample presented symptoms of positive depression. Additionally, almost half reported symptoms of anxiety due to the pandemic. We emphasize that the greatest number of cases and deaths in the first months took place at the end of July $2020^{(14)}$, period when the symptoms of depression were investigated in the participants of this research. A study conducted in the Middle East that aimed to verify the effect of the pandemic on mental suffering of health care students and professions identified double the cases of moderately severe or severe depression $(66.6 \%)$, when compared to our study (also verified by PHQ-9) and $36.7 \%$ presented severe anxiety symptoms ${ }^{(5)}$. This difference may be related to the fact that most participants in the mentioned study ${ }^{(5)}$ were health professionals who worked on the front line of care of COVID-19 patients, whereas the fear of contracting the disease and spreading it to family members potentiated the depressive symptoms.

Because it is a complex disease with characteristics that are still little known, COVID-19 has generated uncertainty, anxiety, and fear in the population, feeling potentiated by the inexistence of effective treatment. One must remember that there was obviously no vaccine available in the first months of the pandemic, and Brazil would only begin vaccinating its population about a year after the first case of the disease was identified in the country.

Table 1 - Sociodemographic characteristics and depression symptom indicators (PHQ-9) found in students and professionals, Brazil, 2020 (N=550)

\begin{tabular}{|c|c|c|c|c|c|c|}
\hline \multirow{2}{*}{ Variables } & & \multicolumn{3}{|c|}{ Depression (PHQ-9) [n (\%)] } & \multirow{2}{*}{$\begin{array}{c}\text { Un-adjusted } \\
\text { Odds Ratio } \\
\text { (CI 95\%) }\end{array}$} & \multirow{2}{*}{$\begin{array}{l}\text { Adjusted } \\
\text { Odds Ratio } \\
\text { (CI 95\%) }\end{array}$} \\
\hline & & Total & Positive & Negative & & \\
\hline \multirow[t]{2}{*}{ Gender } & Female & 394 (71.6) & $149(37.8)^{\ddagger *}$ & $245(62.2)$ & $1.95(1.28 ; 2.98)^{*}$ & $2.00(1.27 ; 3.18)^{*}$ \\
\hline & Male & $156(28.4)$ & $37(23.7)$ & $119(76.3)$ & Ref. & Ref. \\
\hline \multirow[t]{2}{*}{ Age group (years) } & $18-29$ & $330(60.0)$ & $130(39.4)^{\ddagger *}$ & $200(60.6)$ & $1.90(1.30 ; 2.77)^{*}$ & $2.05(1.31 ; 3.21)^{*}$ \\
\hline & $\geq 30$ & $220(40.0)$ & $56(25.5)$ & $164(74.5)$ & Ref. & Ref. \\
\hline \multirow[t]{2}{*}{ Education } & Higher education & $240(43.6)$ & $91(37.9)$ & $149(62.1)$ & $1.38(0.96 ; 1.97)$ & $1.08(0.70 ; 1.66)$ \\
\hline & Graduate Education & $310(56.4)$ & $95(30.6)$ & $215(69.4)$ & Ref. & Ref. \\
\hline \multirow[t]{2}{*}{ Race } & White & $341(62.0)$ & $127(37.2)^{\ddagger *}$ & $214(62.8)$ & $1.50(1.03 ; 2.19)^{*}$ & $1.60(1.06 ; 2.42)^{*}$ \\
\hline & Not white & $209(38.0)$ & $59(28.2)$ & $150(71.8)$ & Ref. & Ref. \\
\hline \multirow[t]{2}{*}{ Religion } & Yes & $376(68.4)$ & $116(30.9)$ & $260(69.1)$ & Ref. & Ref. \\
\hline & No & $174(31.6)$ & $70(40.2)^{\ddagger *}$ & $104(59.8)$ & $1.50(1.03 ; 2.19)^{*}$ & $1.64(1.08 ; 2.49)^{*}$ \\
\hline \multirow[t]{5}{*}{ Family income } & $<2 \mathrm{MW}$ & $110(16.5)$ & $48(43.6)^{\ddagger *}$ & $62(56.4)$ & $1.55(0.49 ; 4.83)$ & $1.36(0.40 ; 4.54)$ \\
\hline & $2-3 \mathrm{MW}$ & 108 (19.6) & $40(37.0)$ & $68(63.0)$ & $1.18(0.37 ; 3.68)$ & $1.33(0.39 ; 4.43)$ \\
\hline & 3-4 MW & 103 (18.7) & $36(35.0)$ & $67(65.0)$ & $1.07(0.34 ; 3.38)$ & $1.34(0.40 ; 4.49$ \\
\hline & $>4 \mathrm{MW}$ & $214(38.9)$ & $57(26.6)$ & $157(73.4)$ & $0.72(0.24 ; 2.21)$ & $1.09(0.34 ; 3.54)$ \\
\hline & Did not inform & $15(2.7)$ & $5(33.3)$ & $10(66.7)$ & Ref. & Ref. \\
\hline \multirow[t]{2}{*}{ Work } & Yes & $337(61.3)$ & 103 (30.6) & $234(69.4)$ & Ref. & Ref. \\
\hline & No & $213(38.7)$ & $83(39.0)^{\ddagger *}$ & $130(61.0)$ & $1.45(1.01 ; 2.07)^{*}$ & $1.06(0.69 ; 1.62)$ \\
\hline \multirow[t]{2}{*}{ Financial struggles } & Yes & $151(27.5)$ & $80(53.0)^{\ddagger *}$ & $71(47.0)$ & $3.11(2.11 ; 4.59)^{*}$ & $2.40(1.52 ; 3.79)^{*}$ \\
\hline & No & $399(72.5)$ & $106(26.6)$ & $293(73.4)$ & Ref. & Ref. \\
\hline \multirow[t]{2}{*}{ Family issues } & Yes & 207 (37.6) & $98(47.3)^{\ddagger *}$ & $109(52.7)$ & $2.60(1.80 ; 3.75)^{*}$ & $1.77(1.17 ; 2.68)^{*}$ \\
\hline & No & $343(62.4)$ & $88(25.7)$ & $255(74.3)$ & Ref. & Ref. \\
\hline \multirow[t]{3}{*}{ Marital relationship } & Tranquil & $240(43.6)$ & $68(28.3)$ & $172(71.7)$ & $0.76(0.52 ; 1.12)$ & $0.877(0.57 ; 1.35)$ \\
\hline & Troubled or mixed & $61(11.1)$ & $33(54.1)^{\ddagger *}$ & $28(45.9)$ & $2.27(1.28 .4 .01)^{*}$ & $2.14(1.10 ; 4.15)^{*}$ \\
\hline & I'm single & $249(45.3)$ & $85(34.1)$ & $164(65.9)$ & Ref. & Ref. \\
\hline
\end{tabular}


Table 2 - Depression (PHQ-9) and behaviors during the pandemic period, reported by students and professionals, Brazil, 2020 (N=550)

\begin{tabular}{|c|c|c|c|c|c|c|}
\hline \multirow[t]{2}{*}{ Variables } & & \multicolumn{3}{|c|}{ Depression (PHQ-9) [n (\%)] } & \multirow{2}{*}{$\begin{array}{l}\text { Un-adjusted } \\
\text { Odds Ratio } \\
\text { (CI 95\%) }\end{array}$} & \multirow{2}{*}{$\begin{array}{l}\text { Adjusted } \\
\text { Odds Ratio } \\
\text { (Cl 95\%) }\end{array}$} \\
\hline & & Total & Positive & Negative & & \\
\hline \multirow[t]{2}{*}{ Had COVID-19 } & Yes & $21(3.8)$ & $10(47.6)$ & $11(52.4)$ & $1.82(0.76 ; 4.37)$ & $1.80(0.62 ; 5.21)$ \\
\hline & No & $529(96.2)$ & $176(33.3)$ & $353(66.7)$ & Ref. & Ref. \\
\hline \multirow[t]{2}{*}{ A family member/close person had COVID-19 } & Yes & $274(49.8)$ & $100(36.5)$ & $174(63.5)$ & $1.27(0.89 ; 1.80)$ & $1.15(0.77 ; 1.72)$ \\
\hline & No & $276(50.2)$ & $86(31.2)$ & $190(68.8)$ & Ref. & Ref. \\
\hline \multirow[t]{3}{*}{ Lost their job } & Yes & $54(9.8)$ & $32(59.3)^{\ddagger *}$ & $22(40.7)$ & $2.03(1.07 ; 3.87)^{*}$ & $1.99(0.99 ; 4.00)$ \\
\hline & No & $364(66.2)$ & $99(27.2)$ & $265(72.8)$ & $0.52(0.34 ; 0.79)^{*}$ & $0.53(0.33 ; 0.84)^{*}$ \\
\hline & Did not work & $132(24.0)$ & $55(41.7)$ & $77(58.3)$ & Ref. & Ref. \\
\hline \multirow[t]{2}{*}{ Concerned with the pandemic } & Yes & $514(93.5)$ & $178(34.6)$ & $336(65.4)$ & $1.85(0.82 ; 4.15)$ & $1.0(0.402 ; 2.84)$ \\
\hline & No & $36(6.5)$ & $8(22.2)$ & $28(77.8)$ & Ref. & Ref. \\
\hline \multirow[t]{2}{*}{ Symptoms of anxiety due to the pandemic } & Yes & $343(62.4)$ & $155(45.2)^{\ddagger *}$ & $188(54.8)$ & $4.68(3.02 ; 7.24)^{*}$ & $3.91(2.44 ; 6.27)^{*}$ \\
\hline & No & $207(37.6)$ & $31(15.0)$ & $176(85.0)$ & Ref. & Ref. \\
\hline \multirow[t]{2}{*}{ Victim of violence } & Yes & $48(8.7)$ & $28(58.3)^{\ddagger *}$ & $20(41.7)$ & $3.04(1.66 ; 5.57)^{*}$ & $2.33(1.18 ; 4.55)^{*}$ \\
\hline & No & $502(91.3)$ & $158(31.5)$ & $344(68.5)$ & Ref. & Ref. \\
\hline \multirow[t]{2}{*}{ Participated in festive activity } & Yes & $132(24.0)$ & $39(29.5)$ & $93(70.5)$ & $1.29(0.84 ; 1.97)$ & $1.29(0.78 ; 2.13)$ \\
\hline & No & $418(76.0)$ & $147(35.2)$ & $271(64.8)$ & Ref. & Ref. \\
\hline \multirow[t]{2}{*}{ Use of medications (psychotropics) without medical indication } & Yes & $139(25.3)$ & $75(54.0)^{\ddagger *}$ & $64(46.0)$ & $3.16(2.12 ; 4.71)^{*}$ & $2.94(1.88 ; 4.51)^{*}$ \\
\hline & No & $411(74.7)$ & $111(27.0)$ & $300(73.0)$ & Ref. & Ref. \\
\hline \multirow[t]{2}{*}{ Use of alcoholic beverages to relieve tension, stress, or anxiety } & Yes & $335(60.9)$ & $121(36.1)$ & $214(63.9)$ & $1.30(0.90 ; 1.88)$ & $0.99(0.64 ; 1.52)$ \\
\hline & No & $215(39.1)$ & $65(30.2)$ & $150(69.8)$ & Ref. & Ref. \\
\hline \multirow[t]{3}{*}{ Increased use of illicit drugs } & Yes & $27(4.9)$ & $16(59.3)^{*}$ & $11(40.7)$ & $2.99(1.35 ; 6.63)^{*}$ & $2.69(1.08 ; 6.68)^{*}$ \\
\hline & No & $116(21.1)$ & 37 (31.9) & $79(68.1)$ & $0.96(0.62-1.50)$ & $0.71(0.43 ; 1.18)$ \\
\hline & I do not use & $407(74.0)$ & $133(32.7)$ & $274(67.3)$ & Ref. & Ref. \\
\hline
\end{tabular}

Adjusted Odds Ratio. $C l=$ Confidence interval. ${ }^{\ddagger}$ Pearson chi-square test. ${ }^{*} P$ value $\leq 0.05$ MW $=$ Minimum wage. $(B R L 1,045.00$ or USD 183,91)

In a scenario of unpredictability and uncertainty, isolation exposes the population to stressful situations, rift in social ties, loss of job and income, withdrawal from in person educational and work activities ${ }^{(15)}$ in view of the elevated risk of virus transmission and illness. Other studies showed symptoms of positive depression among students ${ }^{(9,16)}$ and professionals ${ }^{(17)}$, so that the rates of depression onset tripled (from $8.5 \%$ to $27.8 \%$ ) during the pandemic among the US population ${ }^{(6)}$. We found that the increase in vulnerability to mental disorders, directly or indirectly potentiated by the pandemic, has affected a substantial number of people from different social strata and regions of the country, showing the need for emergent interventions within the mental health field.

The consequences of the COVID-19 pandemic are numerous and have exposed thousands of people to situations of biopsychosocial vulnerability. The feeling of insecurity regarding the future is heightened by the abrupt changes in habits and lifestyles, precarious health care, potential risks of morbidity and mortality and loss of family members and friends. The excess of information disseminated also contributes to the increase in social tension, but the indiscriminate dissemination of misinformation (fake news) by digital medias, increasing uncertainties about post-pandemic life ${ }^{(18)}$.

An interesting datum found was the evidence of positive depression among the younger individuals, an age group considered at psychosocial risk for the development of potential mental disorders ${ }^{(15)}$ due to the changes inherent to the transition to adulthood ${ }^{(19)}$, but also a group considered to be at minimal risk for contracting more severe forms of COVID-19. This age group was most affected by psychological symptoms among the US population, with high rates of mental suffering during the pandemic (24.\% [Cl 95\%, 16.3\% -33.8\%]) and an increment in heightened dysphoric feelings, especially loneliness. This increase may be related to forced isolation, fear of contracting SARS-CoV-2, financial deficit, insecurity related to the pandemic outcome ${ }^{(20)}$, interruption in their studies or professional careers. Furthermore, given that most of the participants in our study were graduate students, fears and uncertainties regarding the future that were exacerbated by the delay and worsening of the health crisis can also be considered, emphasizing concerns with the research, the need to reformulate projects, readjust budgets and deadline changes.

Another finding obtained in in our sample was the association between symptoms of depression and racial category in individuals who declared themselves white. This data goes against that of another study ${ }^{(21)}$ that reviewed research results on the relationship between color/race and mental disorders, pointing to a greater rate of mental illness in non-white people. Another study, however, emphasized the association between stressful life events and symptoms of depression in white men, when compared to non-white men ${ }^{(22)}$. An explanatory hypothesis is the fact that this population is more resistant in terms of mental health, against stigma and social inequalities ${ }^{(23)}$. Other factors should be investigated, such as social vulnerability, gender, sociodemographic and economic issues.

Our study identified that, among participants who had negative outcomes because of the pandemic, the rate of positive depression was higher. This may be related to the pandemic scenario itself, which results in important social and economic impacts, 
given that people with low incomes feel more vulnerable in an economically instable environment because many have lost their jobs or prevented from working while the social distancing measures were in place, not to mention the difficulty in predicting the future economic outcome in the post-pandemic period. This scenario of instability generates concerns and uncertainties that contribute to enhance mental suffering, leaving this group in a situation of social helplessness and even more vulnerable to the development of depression ${ }^{(24)}$.

Women in our study had the highest rates and odds ratios for depression during the pandemic when compared to men. Overall, regardless of the period of the pandemic, the depression rate was 1.5 to 3 times higher in females, despite the symptoms, disease course and treatment did not differ when comparing genders ${ }^{(25)}$. In this sense, our results corroborate those of another Brazilian study ${ }^{(15)}$, that also verified mental illness in the adult population during the pandemic, with higher rates of depression among women. This correlation can be explained due to the greater load of tasks placed on women in view of the dual responsibility they undertake related to studies and family dedication, in addition to concerns about providing resources and financial support and well-being to their family members ${ }^{(26)}$. Such burden may be one of the mediating factors in the relationship between mental illness and gender that was identified in our study.

Our studies also indicated a new relationship between depressive symptoms and family troubles, and difficulties in the marital relationship. Other studies ${ }^{(27-28)}$ also highlighted the impact of the pandemic on mental health within the family environment, because of the needs to make new adaptations and adjustments, both in the dynamics of the couple and the children. This correlation can be explained by the abrupt changes that happened in work and study routines, that was transferred to the domestic space, due to the absence of options for leisure outside the home and due to taking care of children fulltime; also, the longer contact time between family members that live in the same home and pressures arising from domestic confinement on parents, children and spouses aggravated the scenario of disagreements and instability among family members, even increasing the rate of exposure to verbal, physical and or psychological violence ${ }^{(27-28)}$.

In this sense, more than half of the participants in our study who suffered violence during the quarantine presented positive depression. The increase in domestic violence was expressed in the samples of several studies conducted in countries such as China, France, Spain, Italy, and the United Kingdom, since with the restriction on transit and extension of social isolation, there was an increase in the population's difficulty to access social and health support mechanisms, or even to escape the violence of abusive families ${ }^{(29)}$. This is related to the fact that isolation promotes longer contact between spouses, generating situations of tension and stress, lack of social contact and fear of being infected by SARS-CoV-2 when leaving home to seek help ${ }^{(30)}$. These factors result in greater female vulnerability to suffering and mental illness ${ }^{(31)}$ and reinforce the importance of keeping a channel for open communication, challenging public policy creators and health professionals to organize other strategies that guarantee access and care, to minimize situations of domestic violence due to health crises related to the pandemic ${ }^{(29)}$.
Another important finding in our study was the association between religion and depression. There has been an increase in studies $^{(32-33)}$ that indicate the role of religious beliefs and their beneficial, such as satisfactory results in mental health ${ }^{(34)}$. In the situation of the pandemic, it remained a protective factor. In the mental health assessment of New York City health professionals, $23 \%$ of the respondents said they adopted religious practices as a resource for dealing with the stress experienced during the period of social isolation ${ }^{(35)}$. These results can be explained by the fact that many people seek and rely on relation to alleviate or minimize suffering, especially when the discomfort involves health problems. Also, positive feelings and spiritual well-being provided by faith make the individual feel stronger when facing their problems, strengthening their hope ${ }^{(36-37)}$. Therefore, the spiritual and support networks that individuals count on must be examined, identifying their motivations, beliefs and convictions, and the importance of this relationship to protecting mental health, and in relation to substance use.

In this aspect, a fact that brought concern was that students/ professionals who reported an increase in the use of illicit drugs and consumption of psychotropic medications without a medical prescription were almost three times more at risk of being among those who presented positive depression. Despite being alarming, the increase in the use of psychoactive substances during the pandemic has been frequently reported and may be related to an attempt to deal with the psychological turmoil brought on by social isolation, exacerbating reactions of anxiety, fear, and uncertainty ${ }^{(38)}$. In this sense, individuals may use substances as an alternative to facing and running from problems, seeking refuge in pleasure, even if momentarily and putting themselves at risk ${ }^{(38)}$.

Furthermore, due to chronic exposure to stress, many people face problems that interfere in the quality and pattern of sleep and rest. The fact that depression has changes in sleep (insomnia or hypersomnia) among its symptoms should also be considered. Many use sleep-inducing or tranquilizers, such as benzodiazepines, to this end. In this sense, there are four important points that deserve to be highlighted: (i) individuals that use benzodiazepines can suffer greater impacts in oxygen supply if affected by severe forms of COVID-19, (ii) the concomitant use of benzodiazepines and alcoholic beverages increases the change for respiratory depression, (iii) the use of alcohol interferes in how the immune system works ${ }^{(39)}$, which leaves the individual more susceptible to complications if affected by severe forms of COVID-19, (iv) the consumption of substances changes individual behavior and can easily lead to non-adherence to preventive behaviors and social isolation rules, the use of masks and care with hand hygiene ${ }^{(40)}$. Added to this is the fact that mental illness is often related to the adoption of unhealthy behaviors, which, in turn, also reduce the performance of the immune function ${ }^{(39)}$. Thus, assessing the factors involved and the relationship between social isolation, the pandemic and depression is essential to plan and promote interventions that can minimize direct and indirect damages caused by the sanitary crisis.

Actions such as opening spaces, even if virtual, to welcome and promote social activities in a planned and positive way ${ }^{(38)}$ have been recommended, trying to minimize the impacts of stress ${ }^{(41-42)}$ so that people are encouraged to adopt healthy behaviors 
and minimize the use of substances as a coping mechanism. Health professionals should help individuals in their processes of transitioning and changing to healthy habits, in their search for pleasurable activities, encouraging regular physical exercise, behavioral interventions and monitoring, including the offer of strategies that can be implemented by phone or any other remote communication resource.

This does not mean that only the individuals affected by COVID-19 need attention and care, since the entire population is facing a very delicate and critical time. Thus, the preventive and care recommendations for the entire population ${ }^{(43-44)}$ should be preserved, which should contemplate mental health preservation more broadly by stimulating the participation of mental health multi-professional teams, making official channels that spread qualified and updated information to the public available, offering training in stress, trauma, anxiety and risk behavior management protocols, investing in the development of innovative actions and alternative service channels (applicates, sites, phone) ${ }^{(45)}$.

\section{Study Limitations}

This study has some limitations. First, the fact that questionnaires were applied exclusively online, which may have caused the information to be omitted or distorted. This omission may be related to memory bias since most of the questions were related to situations that had already occurred some time ago.. Second, we only assessed the prevalence rate of depression during the pandemic (current depression), therefore, there is no way to compare both moments (before and during the pandemic) to establish causal relationships

\section{Contributions to the field of Nursing and Health}

Given the importance of the theme and the scarcity of literature on the issues related to depression during the pandemic by higher education students and professions, we consider that the results of our study contribute to rethinking intervention strategies aimed at the protection of vulnerable groups, considering the inequalities in access to health. It is important to implement institutional policies aimed at the mental health of the population in the many health settings, and that professionals can continue to provide the necessary care and monitoring by phone or digital platforms. As a priority, this monitoring must be directed at the individuals at greater risk of vulnerability, implementing multiprofessional, integrated, and organized work.

\section{CONCLUSION}

Our study showed that the social isolation of students and professionals during the pandemic was associated with depression. The potential associated factors were related to the female gender, young, white and that suffered violence during quarantine. An increase in the use of illicit drugs, excessive concern with the spread of the disease, consumption of medications (sedatives/ hypnotics) without a medical prescription, increased use of illicit substances and conflicting relationships was also found.

The COVID-19 pandemic increased mental health related symptoms among the population and should be managed in the health system. It is probable that we will have to seek practical solutions and collective preventive and health promotion measures to face the challenges set on by the mental decline of the population after the pandemic, in a way to relieve the burden on the health system. To achieve this, it is important to identify the factors involved in the relationship between social isolation and depression, to implement strategies aimed at minimizing the damage to the mental health of the population during the pandemic.

\section{FUNDING}

Assistance from the Graduate Support Program (PROAP/CAPES) of the Graduate Program in Psychiatric Nursing at the Ribeirão Preto College of Nursing. University of Sao Paulo.

Scholarship from the Social Demand Program (DS) of the Coordination for the Improvement of Higher Education Personnel (CAPES) - Brazil - Doctoral Level.

\section{REFERENCES}

1. Lai J, Ma S, Wang Y, Cai Z, Hu J, Wei N, et al. Factors associated with mental health outcomes among health care workers exposed to coronavirus disease 2019. JAMA Netw Open. 2020;3(3):e203976. https://doi.org/10.1001/jamanetworkopen.2020.3976

2. Brooks SK, Webster RK, Smith LE, Woodland L, Wessely S, Greenberg N, et al. The psychological impact of quarantine and how to reduce it: rapid review of the evidence. Lancet, 2020;395:912-920. https://doi.org/10.1016/S0140-6736(20)30460-8

3. Camacho-Zuñiga C, Pego L, Escamilla J, Hosseini S. The impact of the COVID-19 pandemic on students' feelings at high school, undergraduate, and postgraduate levels. Heliyon. 2021;7(3):e06465. https://doi.org/10.1016/j.heliyon.2021.e06465

4. Kwong ASF, Pearson RM, Adams MJ, Northstone K, Tilling K, Smith D, et al. Mental health before and during the COVID-19 pandemic in two longitudinal UK population cohorts. Br J Psychiatry. 2020;218(6):334-43. https://doi.org/10.1192/bjp.2020.242

5. Alsairafi Z, Naser AY, Alsaleh FM, Awad A, Jalal Z. Mental Health Status of Healthcare Professionals and Students of Health Sciences Faculties in Kuwait during the COVID-19 Pandemic. Int J Environ Res Public Health. 2021;18(4):2203. https://doi.org/10.3390/ijerph18042203

6. Ettman CK, Abdalla SM, Cohen GH, Sampson L, Vivier PM, Galea S. Prevalence of depression symptoms in US adults before and during the COVID-19 Pandemic. JAMA Netw Open. 2020;3(9):e2019686. https://doi.org/10.1001/jamanetworkopen.2020.19686

7. Dal'Bosco EB, Floriano LSM, Skupien SV, Arcaro G, Martins AR, Anselmo ACC. Mental health of nursing in coping with COVID-19 at a regional university hospital. Rev Bras Enferm. 2020;73(supl.2):e20200434. https://doi.org/10.1590/0034-7167-2020-0434 
8. Santos KMRD, Galvão MHR, Gomes SM, Souza TAD, Medeiros ADA, Barbosa IR. Depressão e ansiedade em profissionais de enfermagem durante a pandemia da COVID-19. Esc Anna Nery. 2021;25(spe). https://doi.org/10.1590/2177-9465-EAN-2020-0370

9. Maia BR, Dias PC. Ansiedade, depressão e estresse em estudantes universitários: o impacto da COVID-19. Estud Psicol. 2020;37:e200067. https://doi.org/10.1590/1982-0275202037e200067

10. Killgore WDS, Cloonen SA, Taylor EC, Dailey NS. Loneliness: a signature mental health concern in the era of COVID-19. Psychiatry Res. 2020;290:113117. https://doi.org/10.1016/j.psychres.2020.113117

11. Von Elm E, Altman DG, Egger M, Pocock SJ, Gøtzsche PC, Vandenbroucke JP, et al. The strengthening the Reporting of Observational Studies in Epidemiology (STROBE) statement: guidelines for reporting observational studies. Int J Surg. 2014;12(12):1495-9. https://doi. org/10.1016/j.ijsu.2014.07.013

12. Eysenbach G. Improving the quality of Web surveys: the Checklist for Reporting Results of Internet E-Surveys (CHERRIES). J Med Internet Res. 2004;6(3):e34. https://doi.org/10.2196/jmir.2042

13. Kroenke K, Spitzer RL, Williams JB. The PHQ-9: validity of a brief depression severity measure. J Gen Intern Med. 2001;16(9):606-13. https:// doi.org/10.1046/j.1525-1497.2001.016009606.x

14. Ministério da Saúde (BR). Painel de casos de doença pelo coronavírus 2019 (COVID-19) no Brasil [Internet]. Secretarias Estaduais de Saúde. 2020 [cited 2020 Nov 09]. Available from: https://covid.saude.gov.br/

15. Barros MBA, Lima MG, Malta DC, Szwarcwald CL, Azevedo RCS, Romero D, et al. Report on sadness/depression, nervousness/anxiety and sleep problems in the Brazilian adult population during the COVID-19 pandemic. Epidemiol Serv Saúde. 2020;29(4):e2020427. https://doi. org/10.1590/s1679-49742020000400018

16. Mulyadi M, Tonapa SI, Luneto S, Lin WT, Lee BO. Prevalence of mental health problems and sleep disturbances in nursing students during the COVID-19 pandemic: a systematic review and meta-analysis. Nurse Educ Pract. 2021;57:103228. https://doi.org/10.1016/j. nepr.2021.103228

17. Santos KMR, Galvão MHR, Gomes SM, Souza TA, Medeiros AA, Barbosa IR. Depressão e ansiedade em profissionais de enfermagem durante a pandemia da Covid-19. Esc Anna Nery. 2021;25(spe):e20200370. https://doi.org/10.1590/2177-9465-EAN-2020-0370

18. Hansel TC, Saltzman LY, Bordnick PS. Behavioral health and response for COVID-19. Disaster Med Public Health Prep. 2020;14(5):670-6. https://doi.org/10.1017/dmp.2020.180

19. Lopez MRA, Ribeiro JP, Ores LC, Jansen K, Souza LDM, Pinheiro RT, et al. Depressão e qualidade de vida em jovens de 18 a 24 anos no sul do Brasil. Rev Psiquiatr Rio Gd Sul. 2011;33(2):103-8. https://doi.org/10.1590/S0101-81082011005000001

20. McGinty EE, Presskreischer R, Han H, Barry CL. Psychological distress and loneliness reported by US adults in 2018 and April 2020. JAMA. 2020;324(1):93-94. https://doi.org/10.1001/jama.2020.9740

21. Smolen JR, Araújo EM. Raça/cor da pele e transtornos mentais no Brasil: uma revisão sistemática. Ciênc Saúde Colet. 2017;22(12):4021-30. https://doi.org/10.1590/1413-812320172212.19782016

22. Assari S, Lankarani MM. Association between stressful life events and depression; intersection of race and gender. J Racial Ethn Health Disparities. 2016;3(2):349-56. https://doi.org/10.1007/s40615-015-0160-5

23. Keyes CL. The Black-White paradox in health: flourishing in the face of social inequality and discrimination. J Pers. 2009;77(6):1677-706. https://doi.org/10.1111/j.1467-6494.2009.00597.x

24. Lei L, Huang X, Zhang S, Yang J, Yang L, Xu M. Comparison of prevalence and associated factors of anxiety and depression among people affected by versus people unaffected by quarantine during the COVID-19 epidemic in southwestern China. Med Sci Monit. 2020;26:e924609. https://doi.org/10.12659/MSM.924609

25. American Psychiatric Association (APA). Manual diagnóstico e estatístico de transtornos mentais: quinta edição (DSM-V) [Internet]. 5. ed. Porto Alegre: Artmed; 2014 [cited 2021 May 10]. Available from: http://www.niip.com.br/wp-content/uploads/2018/06/Manual-Diagnosicoe-Estatistico-de-Transtornos-Mentais-DSM-5-1-pdf.pdf

26. Ferreira HG. Gender differences in mental health and beliefs about Covid-19 among elderly internet users. Paidéia (Ribeirão Preto). 2021;31:e3110. https://doi.org/10.1590/1982-4327e3110

27. Fegert JM, Vitiello B, Plener PL, Clemens V. Challenges and burden of the Coronavirus 2019 (COVID-19) pandemic for child and adolescent mental health: a narrative review to highlight clinical and research needs in the acute phase and the long return to normality. Child Adolesc Psychiatry Mental Health. 2020;14:20. https://doi.org/10.1186/s13034-020-00329-3

28. Heilborn MLA, Peixoto CE, Barros MML. Tensões familiares em tempos de pandemia e confinamento: cuidadoras familiares. Physis. 2020;30(2):e300206. https://doi.org/10.1590/S0103-73312020300206

29. Gulati G, Kelly BD. Domestic violence against women and the COVID-19 pandemic: What is the role of psychiatry?. Int J Law Psychiatry. 2020;71:101594. https://doi.org/10.1016/j.ijlp.2020.101594

30. Santos LL, Viegas LB, Teixeira ML, Oliveira RCM, Barbosa VVS, Reis LD. O isolamento social como gatilho para a violência contra mulheres na vivência de pandemia. RSD. 2020;9(8):e719986104-e719986104. https://doi.org/10.33448/rsd-v9i8.6104

31. Oliveira W, Magrin J, Andrade A, Micheli D, Carlos D, Fernandez J, et al. Violência por parceiro íntimo em tempos da COVID-19: scoping review. Psicol Saúde Doenças. 2020;21(3):606-23. https://doi.org/10.15309/20psd210306 
32. Tsaras K, Papathanasiou IV, Mitsi D, Veneti A, Kelesi M, Zyga S, et al. Assessment of depression and anxiety in breast cancer patients: prevalence and associated factors. Asian Pac J Cancer Prev. 2018;19(6):1661-9. https://doi.org/10.22034/APJCP.2018.19.6.1661

33. Santero M, Daray FM, Prado C, Hernández-Vásquez A, Irazola V. Association between religiosity and depression varies with age and sex among adults in South America: evidence from the CESCAS I study. PLoS One. 2019;14(12):e0226622. https://doi.org/10.1371/journal. pone.0226622

34. Kent BV, Stroope S, Kanaya AM, Zhang Y, Kandula NR, Shields AE. Private religion/spirituality, self-rated health, and mental health among US South Asians. Qual Life Res. 2020;29(2):495-504. https://doi.org/10.1007/s11136-019-02321-7

35. Shechter A, Diaz F, Moise N, Anstey DE, Ye S, Agarwal S, et al. Psychological distress, coping behaviors, and preferences for support among New York healthcare workers during the COVID-19 pandemic. Gen Hosp Psychiatry. 2020;66:1-8. https://doi.org/10.1016/j. genhosppsych.2020.06.007

36. Murakami R, Campos CJG. Religião e saúde mental: desafio de integrar a religiosidade ao cuidado com o paciente. Rev Bras Enferm. 2012;65(2):361-367. https://doi.org/10.1590/S0034-71672012000200024

37. Strelhow MRW, Bedin LM, Sarriera JC. Children's Religious Coping Scale: adaptation and psychometric properties. Paidéia (Ribeirão Preto). 2017;27(66):107-16, https://doi.org/10.1590/1982-43272766201713

38. Rojas-Jara C. Cuarentena, aislamiento forzado y uso de drogas. Cuad Neuropsicol [Internet]. 2020[cited 2020 Nov 09];14(1):24-8. Available from: https://www.cnps.cl/index.php/cnps/article/view/395

39. World Health Organization (WHO). Food and nutrition tips during self-quarantine [Internet]. 2020 [cited 2020 Jun 18]. Available from: https://www.euro.who.int/en/health-topics/health-emergencies/coronavirus-covid-19/technical-guidance/ food-and-nutrition-tips-during-self-quarantine

40. Andrade G, Couto FS, Câmara-Pestana L. Recommendations about the use of psychotropic medications during the COVID-19 Pandemic. Acta Med Port. 2020;33(13). https://doi.org/10.20344/amp.13976

41. Oliveira WA, Oliveira-Cardoso EA, Silva JL, Santos MA. Impactos psicológicos e ocupacionais das sucessivas ondas recentes de pandemias em profissionais da saúde: revisão integrativa e lições aprendidas. Estud Psicol (Campinas). 2020;37:e200066. https://doi. org/10.1590/1982-0275202037e200066

42. Oliveira WA, Andrade ALM, Souza VLT, De Micheli D, Fonseca LMM, Andrade LS, et al. COVID-19 pandemic implications for education and reflections for school psychology. Psicol Teor Prat. 2021;23(1):1-26. https://doi.org/10.5935/1980-6906/ePTPC1913926

43. Santos MA, Oliveira WA, Oliveira-Cardoso EA. Inconfidências de abril: impacto do isolamento social na comunidade trans em tempos de pandemia de COVID-19. Psicol Soc. 2020;32:e020018. https://doi.org/10.1590/1807-0310/2020v32240339

44. Oliveira-Cardoso EA, Silva BCA, Santos JH, Lotério LS, Accoroni AG, Santos MA. The effect of suppressing funeral rituals during the COVID-19 pandemic on bereaved families. Rev Latino-am Enfermagem. 2020;28:e3361. https://doi.org/10.1590/1518-8345.4519.3361

45. Xiang YT, Yang Y, Li W, Zhang L, Zhang Q, Cheung T, et al. Timely mental health care for the 2019 novel coronavirus outbreak is urgently needed. Lancet Psychiatry. 2020;7:228-9. https://doi.org/10.1016/S2215-0366(20)30046-8 